\title{
$A$ Ferrocene-Containing Polymer via the Biginelli Reaction for In Vivo Treatment of Oxidative Stress Damage
}

Tengfei Mao ${ }^{\mathrm{a}, \mathrm{b}, \#}$, Lei Yang, ${ }^{\mathrm{c}, \#}$, Guoqiang Liu ${ }^{\mathrm{a}}$, Yen Wei ${ }^{\mathrm{a}}$, Yanzi Gou*b, Jun Wang*b, Lei Tao*a

a The Key Laboratory of Bioorganic Phosphorus Chemistry \& Chemical Biology (Ministry of Education), Department of Chemistry, Tsinghua University, Beijing 100084, P. R. China.

b Science and Technology on Advanced Ceramic Fibers and Composites Laboratory, National University of Defense Technology, Changsha, 410073, P. R. China.

${ }^{\mathrm{c}}$ Cancer Institute \& Hospital, Peking Union Medical College \& Chinese Academy of Medical Science, Beijing, 100021, P. R. China.

\section{EXPERIMENTAL SECTION}

\section{Materials}

All chemicals, reagents, and solvents were purchased from commercial sources and used without further purification. 2-(Acetoacetoxy) ethyl methacrylate (AEMA, Aladdin, 95\%), ferrocenecarboxaldehyde (Innochem Co., Ltd, > 98\%), benzaldehyde (Aladdin, > 99.5\%), ferrocenecarboxylic acid (FcA, Energy Chemical Reagent Co., Ltd, AR), 2-hydroxyethyl methacrylate (HEMA, Aladdin, 95\%), dicyclohexylcarbodiimide (DCC, Aladdin, 99\%), 4-dimethylaminopyridine (DMAP, J\&K, 99\%), $\mathrm{MgCl}_{2}$ (Sinopharm Chemical Reagent Co., Ltd, AR, 99\%), poly(ethylene glycol) methyl ether methacrylate (PEGMA-950, average $\mathrm{M}_{\mathrm{n}} \sim 950 \mathrm{~g} / \mathrm{mol}$, Sigma-Aldrich), 2,2'azobisisoheptonitrile (ABVN, Energy Chemical Reagent Co., Ltd, AR), tert-butyl 
hydroperoxide ( $t$-BHP, Adamas, 70\% solution in water), glutathione (Heowns, 97\%), ascorbic acid (vitamin C, J\&K, 99\%), 2, 2'-azino-bis (3-ethylbenzothiazoline-6sulfonic acid) (ABTS, J\&K, > 98\%), potassium persulfate (J\&K, 99\%), anthocyanidins (Wellgreen Technology Co., Ltd., 90\%), Roswell Park Memorial Institute-1640 (RPMI-1640) culture medium (Corning-Cellgro), phosphate buffered saline (PBS, $\mathrm{pH}$ 7.2-7.4, $0.01 \mathrm{M}, \quad$ Solarbio), silymarin (RuiTaibio, Co., Ltd, > 80\%), polyoxyethylene sorbitan monooleate (Tween $80, \mathrm{~J} \& \mathrm{~K}, \mathrm{CP}$ ), fetal bovine serum (FBS, Gibco), penicillin-streptomycin solution (Gibco), trypsin-EDTA (Gibco, 0.25\%), 4-(3(2-methoxy'-4-nitrophenyl)-2-(4-nitrophenyl)-2H-tetrazol-3-ium-5-yl) benzene-1,3disulfonate (CCK-8, Beyotime), fluorescein diacetate (FDA, Sigma), propidium iodide (PI, 94\%, Sigma), and 2,7-dichlorodihydro-fluorescein diacetate (DCFH-DA, Beyotime) were used as purchased. The homopolymer of PEGMA-950 (P(PEG)) was prepared according to the literature. ${ }^{1}$

\section{Instruments}

Gel permeation chromatography (GPC) analyses of polymers were performed using N, N-dimethyl formamide (DMF) containing $50 \mathrm{mM} \mathrm{LiBr}$ as the eluent. The GPC system was a Shimadzu LC-20AD pump system consisting of an auto injector, a MZGel SDplus $10.0 \mu \mathrm{m}$ guard column $\left(50 \times 8.0 \mathrm{~mm}, 10^{2} \AA\right)$ followed by a MZ-Gel SDplus $5.0 \mu \mathrm{m}$ bead-size column (50 - $10^{6} \AA$, linear), a Shimadzu RID-10A refractive index detector and a Shimadzu SPD-10A UV detector. The system was calibrated with narrow molecular weight distribution polystyrene standards ranging from 200 to $10^{6} \mathrm{~g} \mathrm{~mol}^{-1}$. ${ }^{1} \mathrm{H}$ NMR and ${ }^{13} \mathrm{C}$ NMR spectra were obtained using a JEOL JNM-ECA400 (400 MHz) 
spectrometer for all samples. The ESI-MS data were collected using a Micro TOF-QII Bruker. The FT-IR spectra were recorded in a transmission mode on a Perkin-Elmer Spectrum 100 spectrometer (Waltham, MA, USA). UV-Visible absorption spectra were recorded on a UV/Vis/NIR Perkin-Elmer lambda750 spectrometer (Waltham, MA, USA) using quartz cuvettes of $1 \mathrm{~cm}$ path length. Cell viability was measured via a CCK8 assay by a VICTOR ${ }^{\mathrm{TM}}$ X3 PerkinElmer 2030 Multilabel Plate Reader. Histological images of liver sections were recorded using a light microscope (IX71, Olympus, Japan, $\times 600$ magnification).

\section{Methods}

\subsection{2-(Methacryloyloxy) ethyl 6-methyl-4-ferrocene-dihydropyrimidin-2(1H)-} thione-5-carboxylate (Ferrocene-DHPM monomer)
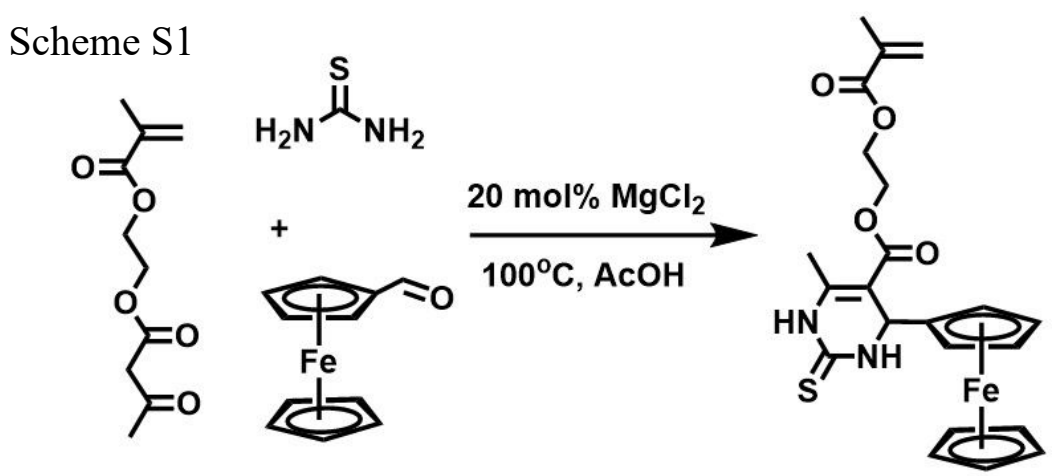

Ferrocenecarboxaldehyde ( $856 \mathrm{mg}, 4.0 \mathrm{mmol})$, AEMA (856 mg, $4.0 \mathrm{mmol}$ ), and thiourea $(456 \mathrm{mg}, 6.0 \mathrm{mmol})$ were put in a $15 \mathrm{~mL}$ centrifuge tube. Then, acetic acid (4.0 mL) and magnesium chloride (76 mg, $0.8 \mathrm{mmol})$ were added. The tube was sealed and put in a $100^{\circ} \mathrm{C}$ isothermal shaker for $4 \mathrm{~h}$. At the end of reaction, the mixture was simply purified by precipitation into cold water, then washed three times by water and then diethyl ether to get the final Ferrocene-DHPM monomer as a black powder (1.63 g, $\sim 87 \%$ yield). 
${ }^{1} \mathrm{H}-\mathrm{NMR}$ (400 MHz, DMSO-d 6 , $\left.\delta / \mathrm{ppm}\right): 10.41$ (s, 1H, CSNHC), 9.44 (d, $J=4.3 \mathrm{~Hz}$, 1H, CSN $\underline{H C H}), 6.05\left(\mathrm{~s}, 1 \mathrm{H}, \mathrm{CH}_{2}=\mathrm{C}\right), 5.73\left(\mathrm{~s}, 1 \mathrm{H}, \mathrm{CH}_{2}=\mathrm{C}\right), 4.92(\mathrm{~d}, J=4 . \mathrm{Hz}, 1 \mathrm{H}$, CSNHC프), 4.36-3.90 (m, 9H, Cp), 4.30-4.10 (m, 4H, $\left.\mathrm{COOCH}_{2} \mathrm{CH}_{2}\right), 2.18(\mathrm{~s}, 3 \mathrm{H}$, $\left.\mathrm{NHCC} \underline{H}_{3}\right), 1.89\left(\mathrm{~s}, 3 \mathrm{H}, \underline{\mathrm{CH}}_{3} \mathrm{C}=\mathrm{CH}_{2}\right)$.

${ }^{13} \mathrm{C}-\mathrm{NMR}$ (100 MHz, DMSO-d 6 , $\left.\delta / \mathrm{ppm}\right): 174.90,166.41,165.00,144.99,135.61$, $126.20,101.93,68.60,67.33,66.19,65.00,62.62,61.72,48.99,18.00,17.06$.

IR (v/cm $\left.{ }^{-1}\right): 3182,3091,2957,1707,1636,1565,1451,1377,1315,1296,1250,1171$, $1100,1039,1001,947,883,816,758,714,654$.

ESI-MS: observed (expected): 468.0798 (468.0801) [M+].

\subsection{2-(Methacryloyloxy) ethyl 6-methyl-4-phenyl-dihydropyrimidin-2(1H)-thione-}

\section{5-carboxylate (Ph-DHPM monomer)}

Scheme S2
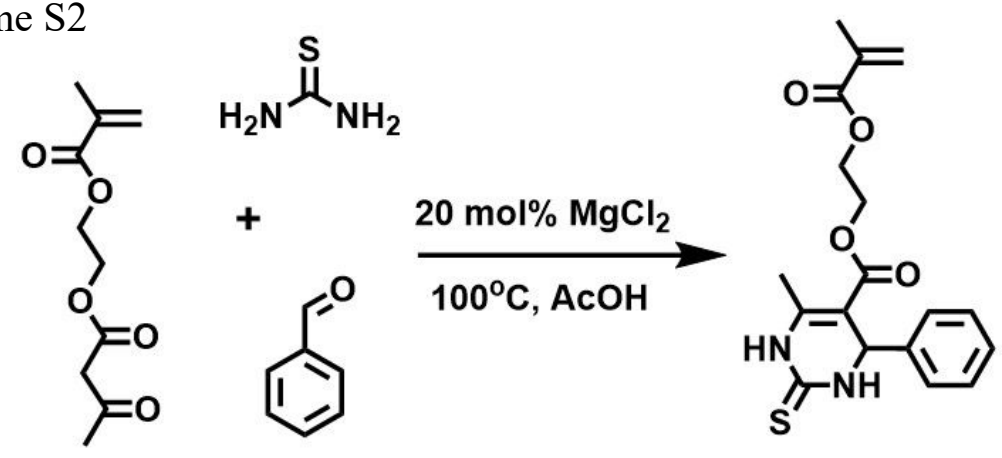

The Ph-DHPM monomer was similarly prepared by abovementioned method using benzaldehyde instead of ferrocenecarboxaldehyde for the Biginelli reaction.

${ }^{1} \mathrm{H}-\mathrm{NMR}$ (400 MHz, DMSO-d $\left.\mathrm{d}_{6}, \delta / \mathrm{ppm}\right): 10.41$ (s, 1H, CSNHC), 9.70 (s, 1H, CSN $\underline{H C H}), 7.30-7.10(\mathrm{~m}, 5 \mathrm{H}, \mathrm{Ph}), 5.95\left(\mathrm{~s}, 1 \mathrm{H}, \mathrm{CH}_{2}=\mathrm{C}\right), 5.66\left(\mathrm{~s}, 1 \mathrm{H}, \mathrm{CH}_{2}=\mathrm{C}\right), 5.16(\mathrm{~d}$, $J=3.7 \mathrm{~Hz}, 1 \mathrm{H}, \mathrm{CSNHC} \underline{\mathrm{H}}), 4.30-4.10\left(\mathrm{~m}, 4 \mathrm{H}, \mathrm{COOCH}_{2} \mathrm{CH}_{2}\right), 2.28(\mathrm{~s}, 3 \mathrm{H}$, $\left.\mathrm{CONHCC} \underline{H}_{3}\right), 1.83\left(\mathrm{~s}, 3 \mathrm{H}, \mathrm{CH}_{3} \mathrm{C}=\mathrm{CH}_{2}\right)$.

${ }^{13} \mathrm{C}-\mathrm{NMR}\left(100 \mathrm{MHz}, \mathrm{DMSO}-\mathrm{d}_{6}, \delta / \mathrm{ppm}\right): 183.94,174.36,172.05,166.36,164.97$, 
$145.78,143.42,135.59,128.58,126.20,100.35,62.50,61.60,53.96,17.95,17.27$.

IR $\left(v / \mathrm{cm}^{-1}\right): 3305,3175,2971,1701,1633,1558,1449,1374,1312,1169,1094,943$,

$875,821,766,698.1$

ESI-MS: observed (expected): 361.1216 (361.1217) $\left[\mathrm{M}+\mathrm{H}^{+}\right]$.

\subsection{2-Methacryloyloxyethyl ferrocenecarboxylate (FcEMA)}

Scheme S3
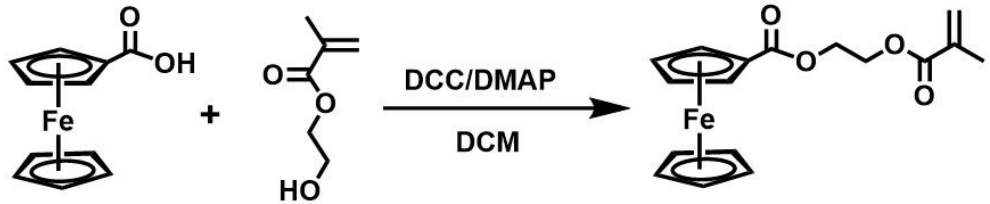

The FcEMA was synthesized through an esterification reaction between ferrocenecarboxylic acid (FcA) and 2-hydroxyethyl methacrylate (HEMA) according to the reference. ${ }^{2}$ A mixture of FcA (9.20 g, $\left.39.94 \mathrm{mmol}\right)$, DMAP (0.24 g, $\left.2.00 \mathrm{mmol}\right)$ and HEMA $(6.8 \mathrm{ml}, 42.58 \mathrm{mmol})$ in dry DCM $(300 \mathrm{~mL})$ was stirred for $60 \mathrm{~min}$. The solution was cooled to $0^{\circ} \mathrm{C}$, then DCC $(10.31 \mathrm{~g}, 50.00 \mathrm{mmol})$ in DCM $(60 \mathrm{~mL})$ was dropwise added to the mixture within $30 \mathrm{~min}$. The reaction mixture was continually stirred for $24 \mathrm{~h}$ at ambient temperature, then filtered to remove 1,3-dicyclohexylurea (DCU). After washing three times by deionized water and saturated $\mathrm{NaHCO}_{3}$, the organic layer was separated, dried over $\mathrm{MgSO}_{4}$, and evaporated to remove volatiles. The crude was purified by column chromatography on silica gel (ethyl acetate: petroleum ether $=1: 9)$ to yield the product as a orange powder $(10.47 \mathrm{~g}, 76.5 \%$ yield $)$. ${ }^{1} \mathrm{H}-\mathrm{NMR}\left(400 \mathrm{MHz}, \mathrm{DMSO}-\mathrm{d}_{6}, \delta / \mathrm{ppm}\right): 6.10\left(\mathrm{~s}, 1 \mathrm{H}, \mathrm{CH}_{2}=\mathrm{C}\right), 5.73\left(\mathrm{~s}, 1 \mathrm{H}, \mathrm{CH}_{2}=\mathrm{C}\right)$, $4.74(\mathrm{t}, 2 \mathrm{H}, J=1.91 \mathrm{~Hz}, \mathrm{CHCCOO}), 4.50$ (t, $2 \mathrm{H}, J=1.91 \mathrm{~Hz}, \mathrm{C} \underline{\mathrm{HCHCCOO}}), 4.40-$ $4.30\left(\mathrm{~m}, 4 \mathrm{H}, \mathrm{COOCH}_{2} \mathrm{CH}_{2}\right), 4.21$ (s, $\left.5 \mathrm{H}, \mathrm{Cp}\right), 1.91\left(\mathrm{~s}, 3 \mathrm{H}, \mathrm{C}_{3} \mathrm{C}=\mathrm{CH}_{2}\right)$.

${ }^{13} \mathrm{C}-\mathrm{NMR}\left(100 \mathrm{MHz}, \mathrm{DMSO}_{6}, \mathrm{~d} / \mathrm{ppm}\right):$ 174.81, 169.53, 135.84, 126.22, 71.63, 70.56, 
$69.92,69.72,62.80,61.94,18.11$.

IR $\left(v / \mathrm{cm}^{-1}\right): 3111,2960,2928,2853,2119,1703,1637,1469,1451,1412,1398,1375$

$1323,1278,1238,1176,1145,1116,1105,1051,1025,1008,958,944,928,873,860$,

$835,824,776$.

ESI-MS: observed (expected): 365.0449 (365.0447) $\left[\mathrm{M}+\mathrm{Na}^{+}\right]$.

\subsection{Preparation of the Ferrocene-DHPM copolymer (P1)}

Scheme S4

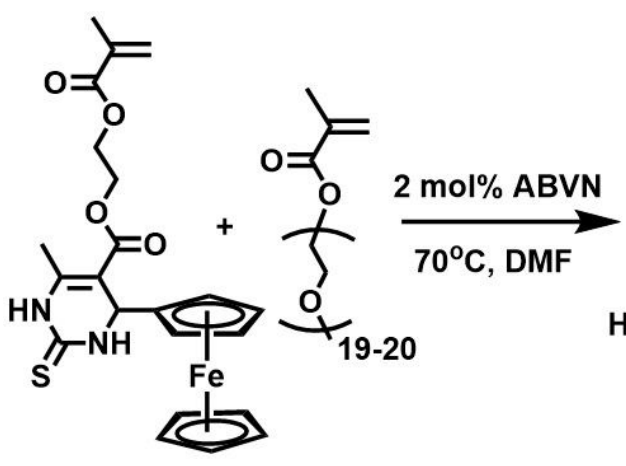

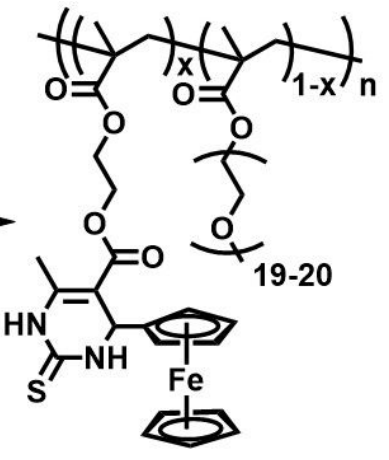

The ferrocene-DHPM monomer (0.47 g, $1.0 \mathrm{mmol})$, PEGMA-950 (0.95 g, 1.0 mmol), and ABVN (0.01 g, $0.04 \mathrm{mmol})$ were charged in a dry Schlenk tube. DMF (2.0 $\mathrm{mL}$ ) was added, and the Schlenk tube was sealed with a rubber septum. Nitrogen was bubbled through the reaction mixture for $15 \mathrm{~min}$ to purge the system from oxygen. The Schlenk tube was then placed in a $70^{\circ} \mathrm{C}$ oil bath for $12 \mathrm{~h}$. At the end of polymerization, a sample $(\sim 50 \mu \mathrm{L})$ was taken for ${ }^{1} \mathrm{H}$ NMR and GPC analyses. The remaining mixture was precipitated in diethyl ether three times, and dried under vacuum. The final product obtained was a viscous and black copolymer (P1, $1.18 \mathrm{~g}, \sim 83 \%)$.

P2 and P3 were similarly prepared using different monomers to copolymerize with PEGMA.

\subsection{Measurement of the radical scavenging ability of copolymers}

The radical scavenging ability of copolymers was measured according to a 
reported method. ${ }^{3-4} \mathrm{ABTS}^{\cdot+}$ was produced from $2.0 \mathrm{~mL}$ of an aqueous solution containing $4.0 \mathrm{mM}$ ABTS and $1.41 \mathrm{mM} \mathrm{K}_{2} \mathrm{~S}_{2} \mathrm{O}_{8}$. After $14 \mathrm{~h}$, this solution was diluted by ethanol until the absorbance (at $734 \mathrm{~nm}$ ) of the mixture was around $0.70\left(\mathrm{ABTS}^{\bullet+} \sim\right.$ $66 \mu \mathrm{M})$. This freshly prepared $\mathrm{ABTS}^{\cdot+}$ solution $(190 \mu \mathrm{L}, \sim 66 \mu \mathrm{M})$ was mixed with an aqueous solution of P1 $(10 \mu \mathrm{L}, 0.2 \mathrm{mM})$. The absorbance of the mixture of $\mathrm{ABTS}^{*+} /$ polymer was recorded at certain time intervals $\left(25^{\circ} \mathrm{C}\right)$. Other polymers $(\mathrm{P} 2$, P3, P(PEG)) were similarly tested. Water served as the blank.

\subsection{Radical scavenging efficiency of copolymers}

P1 aqueous solutions with different concentrations $(0.02,0.04,0.1,0.2,0.4$, and $0.8 \mathrm{mM})$ were prepared. These solutions $(10 \mu \mathrm{L})$ were mixed with ABTS $^{\cdot+}$ solution $(190 \mu \mathrm{L}, \sim 66 \mu \mathrm{M})$, respectively. The absorbance of the mixture of $\mathrm{ABTS}^{\bullet+} /$ polymer $^{2}$ was recorded at different time points $\left(25^{\circ} \mathrm{C} ; \mathrm{t}=0 \mathrm{~min}, 30 \mathrm{~min}\right)$. The ratio between scavenged radical $\left(\mathrm{A}_{734}\left(\mathrm{t}_{0}\right)-\mathrm{A}_{734}\left(\mathrm{t}_{30}\right)\right)$ and the original radical $\left(\mathrm{A}_{734}\left(\mathrm{t}_{0}\right)\right)$ was used to calculate the radical scavenging efficiency. P2 and P3 were parallelly tested.

\subsection{Cell Culture}

L929 cells, a fibroblast cell line from mice, were cultured in a RPMI-1640 medium supplemented with 10\% fetal bovine serum (FBS) and 1\% penicillin and streptomycin. Cells were incubated at $37^{\circ} \mathrm{C}$ and $5 \% \mathrm{CO}_{2}$. Culture medium was changed every two days to maintain the exponential growth of the cells.

\subsection{Cytotoxicity of P1 and small molecules}

The cytotoxicity of P1 and small molecular antioxidants to L929 cells was evaluated using a cell count kit-8 (CCK-8) assay. Typically, cells $\left(\sim 5 \times 10^{4} / \mathrm{mL}\right)$ were 
seeded in a 96-well plate. After attachment, cells were washed with PBS and cultured with different concentrations of P1 in culture medium for $24 \mathrm{~h}$, then washed three times with PBS. The treated cells were incubated in a medium $(100 \mu \mathrm{L})$ containing $10 \%$ CCK-8 at $37^{\circ} \mathrm{C}$ for $2 \mathrm{~h}$ prior to analysis using a microplate reader (VICTORTM X3 PerkinElmer 2030 Multilabel Plate Reader). Viability of cells in pure culture medium was defined as 100\% viability. Small molecular antioxidants (vitamin C, glutathione, and anthocyanidins) were measured in parallel.

\subsection{Cytotoxicity of $t$-BHP to L929 cells}

$t$-BHP (70\% solution in water) was diluted to different concentrations (0 2000 $\mu \mathrm{M})$ with a RPMI 1640 medium. L929 cells $\left(\sim 5 \times 10^{4} / \mathrm{mL}\right)$ were seeded in a $96-$ well plate. After attachment, cells were washed with PBS then cultured with $t$-BHP (0 2000 $\mu \mathrm{M})$ for $24 \mathrm{~h}$. Cells were washed thrice with PBS to get rid of $t$-BHP, then used for a CCK-8 assay to choose a suitable concentration of $t$-BHP for subsequent experiments.

\subsection{Reactive oxygen species (ROS) induced by $t$-BHP}

The ROS levels were measured using a 2, 7-dichlorodihydrofluorescein diacetate (DCFH-DA) probe as previously described. ${ }^{5}$ Typically, L929 cells $\left(\sim 5 \times 10^{4} / \mathrm{mL}\right)$ were seeded in a 96-well plate. After removing the culture medium, cells were washed with a serum-free medium and cultured in a working solution containing DCFH-DA (10 $\mu \mathrm{mol} \mathrm{L}-1,100 \mu \mathrm{L}$ ) at $37^{\circ} \mathrm{C}$ for $1 \mathrm{~h}$. Then, cells were washed with a serum-free medium three times and incubated in a culture medium containing $t$-BHP $(200 \mu \mathrm{M})$. The changes of the fluorescein in cells $(485 \mathrm{~nm} / 535 \mathrm{~nm})$ were collected by a microplate reader (VICTOR ${ }^{\mathrm{TM}}$ X3 PerkinElmer 2030 Multilabel Plate Reader) at different time points (0, 
$1,2,4,6,8 \mathrm{~h})$. The fluorescence intensity of cells in culture medium only was used as the control and defined as $100 \%$; the increased ROS levels were shown as relative fluorescence intensity compared with the control and presented as mean $\pm \mathrm{SD}$.

ROS levels induced by different antioxidants (P1, vitamin $\mathrm{C}$, glutathione, and anthocyanidins) were similarly measured.

\subsection{FDA/PI double staining}

FDA/PI double staining is a rapid and convenient method to simultaneously observe the living cells and dead cells. ${ }^{6}$ Typically, L929 cells $\left(\sim 5 \times 10^{4} / \mathrm{mL}\right)$ were seeded in a 24-well plate and cultured with P1 $(20 \mathrm{mg} / \mathrm{mL})$ and $t$-BHP $(200 \mu \mathrm{M})$ for 24 h. The cells were washed with PBS thrice, then incubated in a PBS-FDA-PI solution (FDA: $3 \mu \mathrm{g} \mathrm{mL} \mathrm{m}^{-1}$; PI: $\left.3 \mu \mathrm{g} \mathrm{mL} \mathrm{g}^{-1}\right)$ for $15 \mathrm{~min}\left(37^{\circ} \mathrm{C}\right)$. A fluorescence microscope (Leica Germany) was used to observe the living and dead cells under 450-490 nm and 515$560 \mathrm{~nm}$ band-pass excitation filters (I3 and N2.1), respectively (100 W mercury lamp). The small molecular antioxidants were parallelly tested. Cells cultured with $t$-BHP (200 $\mu \mathrm{M})$ served as the control. Cells in culture medium only was used as the blank.

\subsection{ROS-resistance by different antioxidants}

The ROS levels were measured through abovementioned method. Typically, L929 cells $\left(\sim 5 \times 10^{4} / \mathrm{mL}\right)$ were seeded in a 96 -well plate. After removing the culture medium, cells were washed with a serum-free medium and cultured in a working solution containing DCFH-DA $(10 \mu \mathrm{mol} \mathrm{L}-1,100 \mu \mathrm{L})$ at $37^{\circ} \mathrm{C}$ for $1 \mathrm{~h}$. Then, cells were washed with a serum-free medium three times and incubated in a culture medium containing $t$ BHP $(200 \mu \mathrm{M})$ and P1 $(20 \mathrm{mg} / \mathrm{mL})$. The changes of the fluorescein in cells $(485 \mathrm{~nm} / 535$ 
$\mathrm{nm})$ were recorded by a microplate reader at different time points $(0,1,2,4,6,8 \mathrm{~h})$. The fluorescence intensity of cells in culture medium only was used as the control and defined as $100 \%$. The increased ROS levels were shown as relative fluorescence intensity compared with the control and presented as mean \pm SD.

ROS-resistance by small molecular antioxidants (vitamin C, glutathione, and anthocyanidins) were similarly tested.

\subsection{Ethical declaration}

All in vivo experiments were performed under the technical guidelines for nonclinical studies, as issued by China Food and Drug Administration. This study was approved by the ethic committee of Chinese Academy of Medical Science Cancer Hospital (permit number: NCL2018A167).

\subsection{Preparation of a silymarin solution}

A solution of silymarin $(20 \mathrm{mg} / \mathrm{mL})$ was prepared as literatures. ${ }^{7}$ Silymarin $(0.5$ g) was dissolved in ethanol $(0.68 \mathrm{~mL})$. Then ethyl acetate $(0.16 \mathrm{~mL})$, ethyl linoleate $(0.30 \mathrm{~mL})$ and Tween-80 (3.20 g) were added, successively. The mixture was dispersed by ultrasonic until pellucid and homogeneous, and then diluted using a glucose solution ( $5 \mathrm{wt} \%$ ) to $25 \mathrm{~mL}$. This solution was sterilized by passing through a membrane (220 $\mathrm{nm})$ prior to use.

\subsection{Doses and administration methods evaluation}

Balb/c mice (30, 5-7-week old, 18-21 g, male and female) were randomly assigned to 5 groups (6 mice/group): 1) intravenous tail injection of $\mathrm{P} 1(20 \mathrm{mg} / \mathrm{mL}, 600 \mu \mathrm{L}) ; 2)$ intravenous tail injection of silymarin $(20 \mathrm{mg} / \mathrm{mL}, 600 \mu \mathrm{L})$ (immediately dead); 3) 
intravenous tail injection of silymarin $(20 \mathrm{mg} / \mathrm{mL}, 200 \mu \mathrm{L})$ (immediately dead); 4) intraperitoneal injection of silymarin $(20 \mathrm{mg} / \mathrm{mL}, 600 \mu \mathrm{L})(5$ dead within $24 \mathrm{~h}) ; 5)$ intraperitoneal injection of silymarin $(20 \mathrm{mg} / \mathrm{mL}, 200 \mu \mathrm{L})$. Mice were fasted overnight but given tap water ad libitum. After 24 h, only mice in group 1 and group 5 survived. The living mice were sacrificed to collect blood and livers for further analyses. Healthy mice served as the blank.

\subsection{Biochemical analyses}

After blood collection, serum was separated by centrifugation (3000 rpm, 20 min, $20^{\circ} \mathrm{C}$ ). The serum alanine aminotransferase (ALT) and aspartate aminotransferase (AST) values were assessed by an automatic Biochemistry Analyzer (Sinnowa, Nanjing, China) at $37^{\circ} \mathrm{C}$.

Livers were excised immediately after the mice were sacrificed. The livers, except a portion of the left lobes for histopathological sections, were frozen quickly and stored at $-80^{\circ} \mathrm{C}$. Prior to determinations, thawed tissue samples $(0.1 \mathrm{~g})$ were homogenized in ice cold physiological saline $(0.9 \mathrm{~g})$, then centrifuged $\left(2500 \mathrm{rpm}, 20 \mathrm{~min}, 4^{\circ} \mathrm{C}\right)$. The hepatic levels of superoxide dismutase (SOD) and malondialdehyde (MDA) were measured according to the protocols of commercially available kits (Jiancheng Institute of Biotechnology, Nanjing, China). SOD activity was expressed as U/mg protein, and MDA level was expressed as nmol/mg protein. In each group, six mice were used for biochemical analyses.

\subsection{Histological analysis}

The liver tissue specimens separated for histopathological examination were fixed 
in a buffered formaldehyde solution $(10 \%, \mathrm{w} / \mathrm{v})$. The fixed tissues were dehydrated with ethanol solutions of differing concentrations $(50-100 \%, v / v)$, then embedded in paraffin, cut into 4-5 $\mu \mathrm{m}$ thick sections and stained with hematoxylin and eosin (H\&E).

\subsection{Statistical Analyses}

Statistically significant analyses were performed using the SPSS 24.0 statisticalsoftware package (SPSS, Inc., Chicago, IL) by one-way analysis of variance (ANOVA) and Student's t-test (two-tailed), where differences were regarded as statistically significant with probability $p<0.05$. Results are presented as mean \pm SD. 


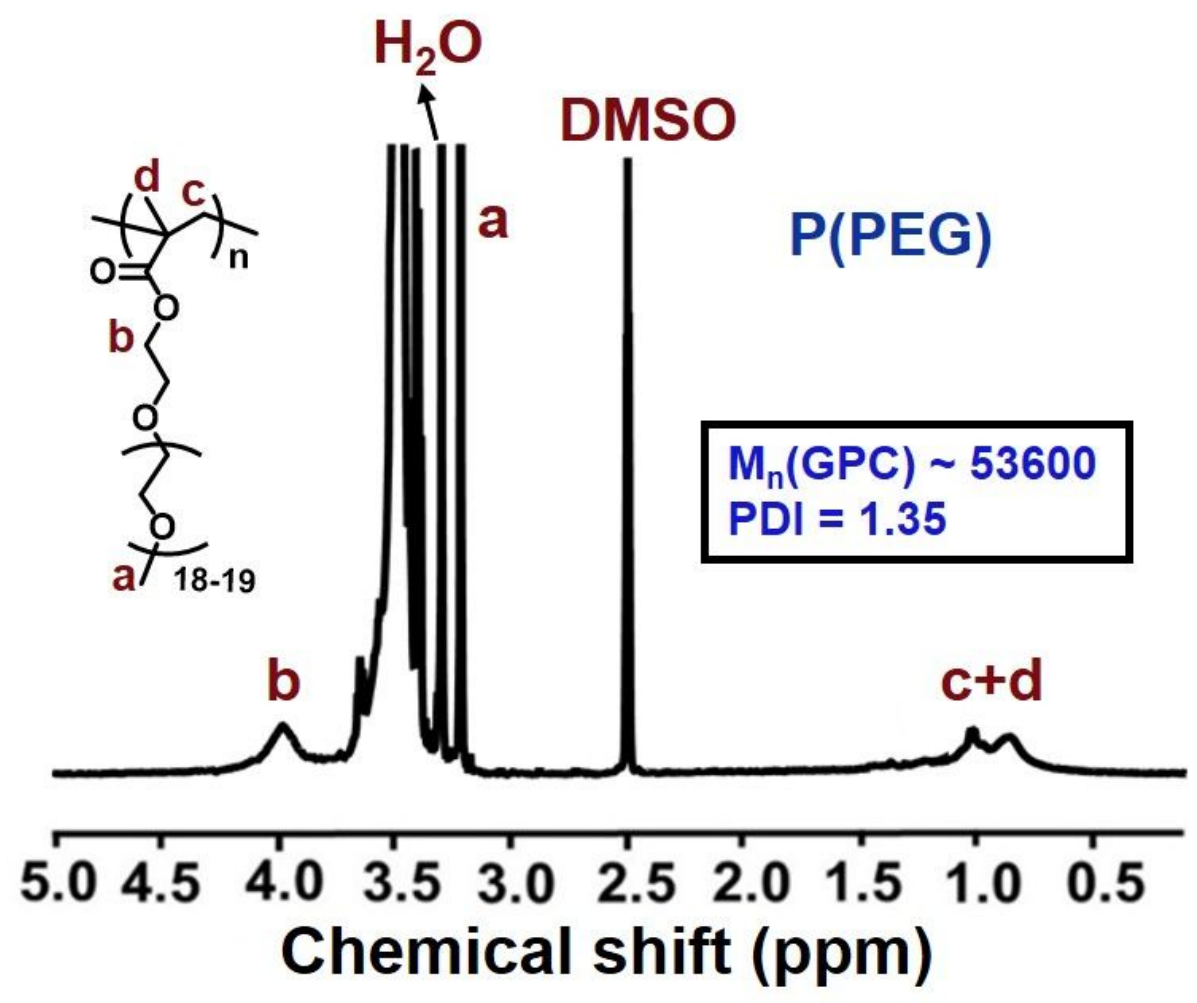

Figure S1. ${ }^{1} \mathrm{H}$ NMR spectrum (DMSO- $\left.d_{6}, 400 \mathrm{M}\right)$ of $\mathrm{P}(\mathrm{PEG})$. 


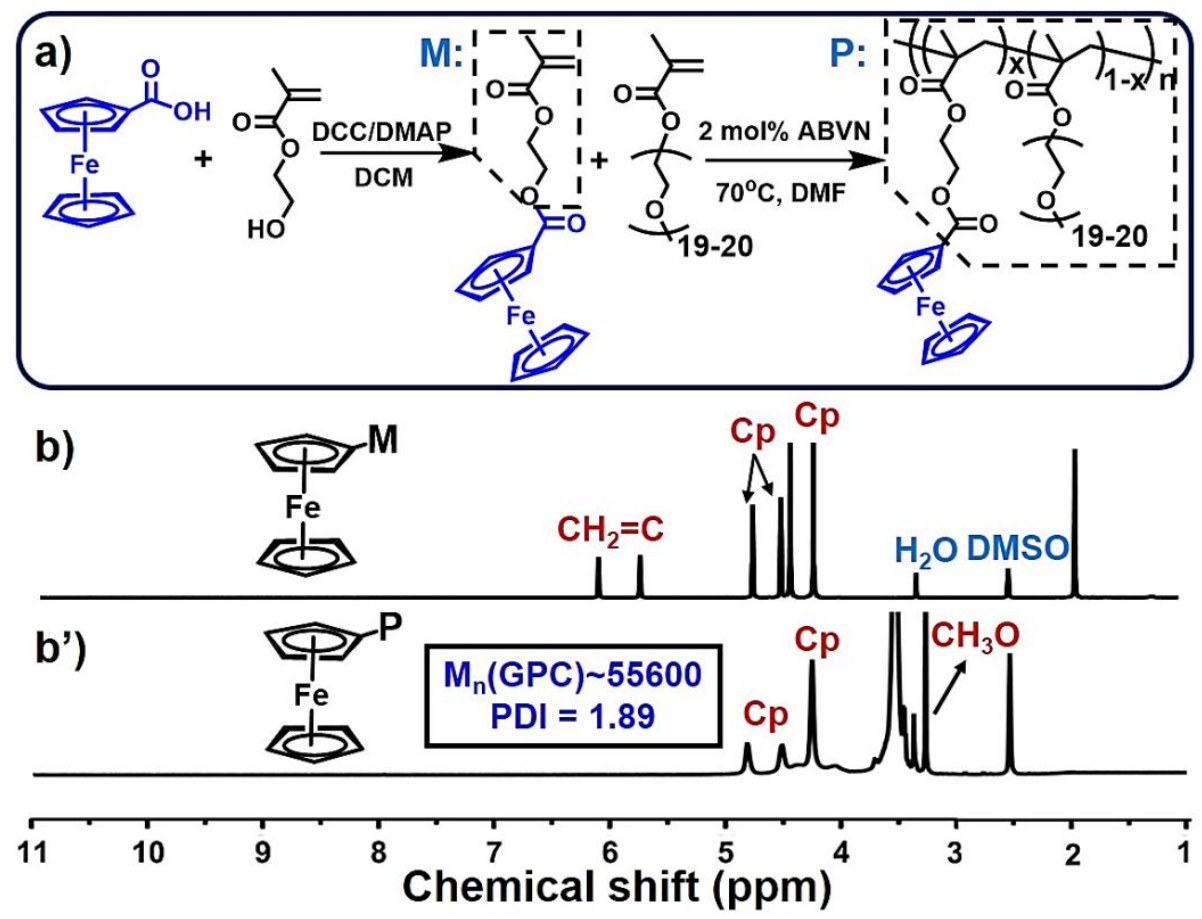

Figure S2. a) Reaction condition: 1) DCM as the solvent, $25^{\circ} \mathrm{C}$, and $24 \mathrm{~h}$; 2) DMF as the solvent, $70^{\circ} \mathrm{C}, 12$ h. FcEMA: PEGMA: ABVN $\left.=0.5: 0.5: 0.02 . \mathrm{b}, \mathrm{b}{ }^{\prime}\right){ }^{1} \mathrm{H}-\mathrm{NMR}$ spectra (DMSO- $\left.d_{6}, 400 \mathrm{M}\right)$ of FcEMA (b) and poly(FcEMA)-co-poly(PEGMA) (P2, b’). 

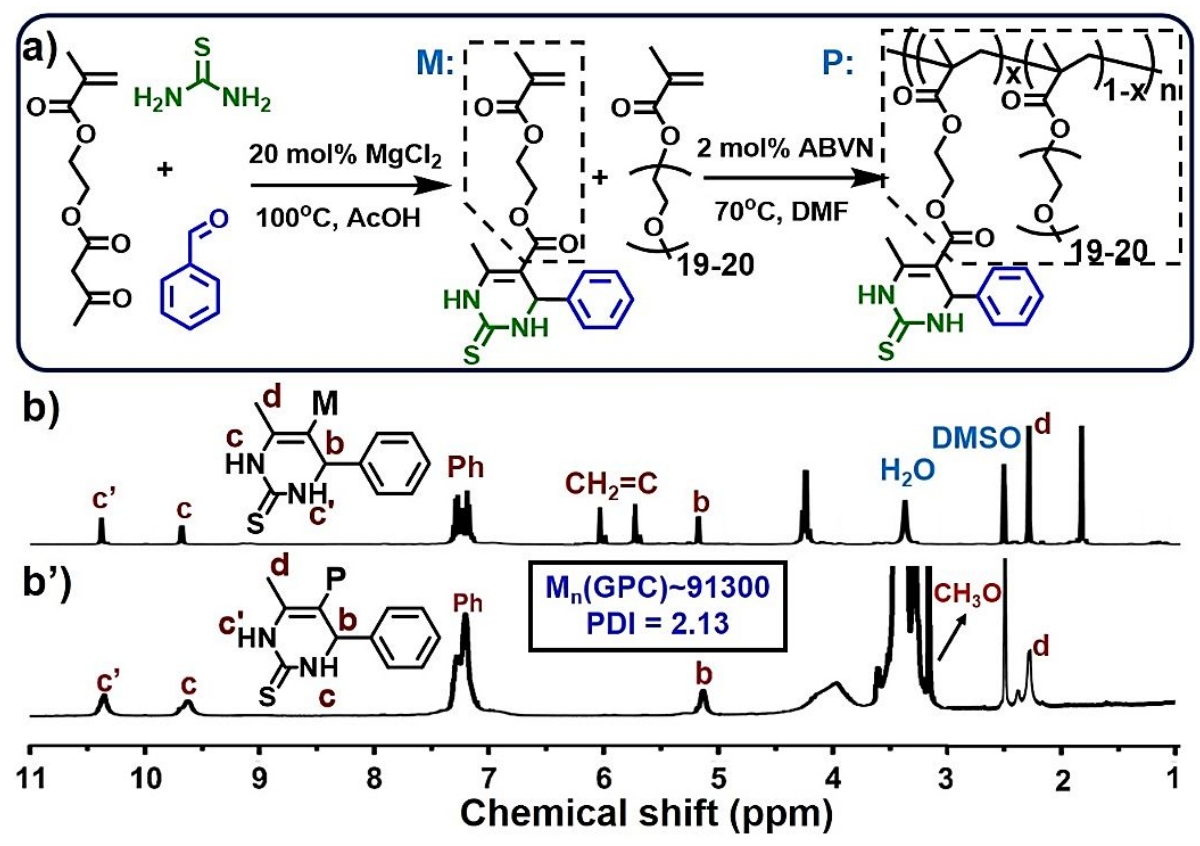

Figure S3. a) Reaction condition: 1) acetic acid as the solvent, $100^{\circ} \mathrm{C}$, and $4 \mathrm{~h}$; 2) DMF as the solvent, $70^{\circ} \mathrm{C}, 12 \mathrm{~h} . \mathrm{Ph}-\mathrm{DHPM}$ monomer: PEGMA: ABVN $=0.5: 0.5: 0.02 . \mathrm{b}$, b') ${ }^{1} \mathrm{H}-\mathrm{NMR}$ spectra (DMSO- $\left.d_{6}, 400 \mathrm{M}\right)$ of Ph-DHPM monomer (b) and poly(PhDHPM)-co-poly(PEGMA) (P3, b'). 


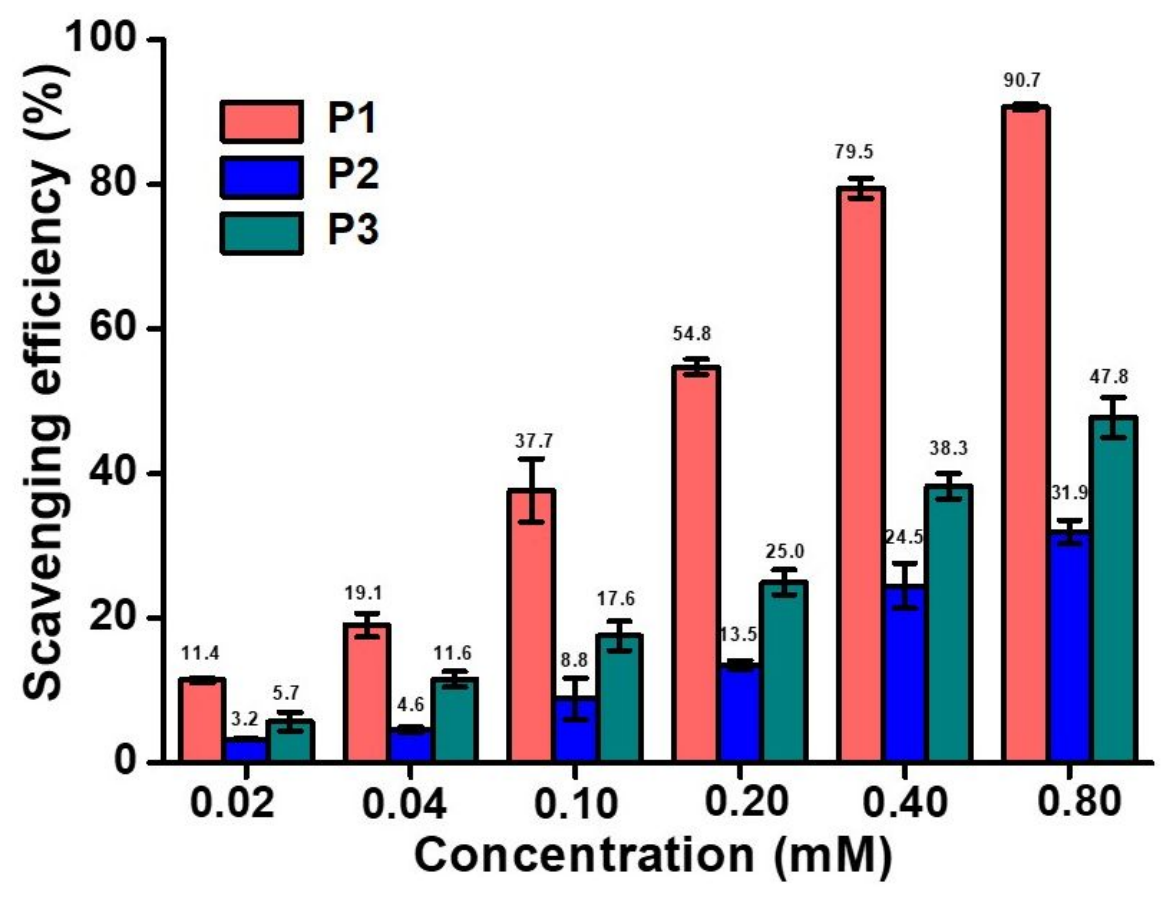

Figure S4. Quantitative evaluation of radical scavenging capability of P1, P2, and P3. ABTS $^{+\bullet}$ solution $(190 \mu \mathrm{L}, \sim 66 \mu \mathrm{M})$ mixed with polymer solutions $(10 \mu \mathrm{L}), 30 \mathrm{~min}$, water served as the blank. Radical scavenging efficiency was calculated as: $\left(\mathrm{A}_{734}\left(\mathrm{t}_{0}\right)\right.$ $\left.\mathrm{A}_{734}\left(\mathrm{t}_{30}\right)\right) / \mathrm{A}_{734}\left(\mathrm{t}_{0}\right) \times 100 \%$. Data presented as mean $\pm \mathrm{SD}, \mathrm{n}=5$. 

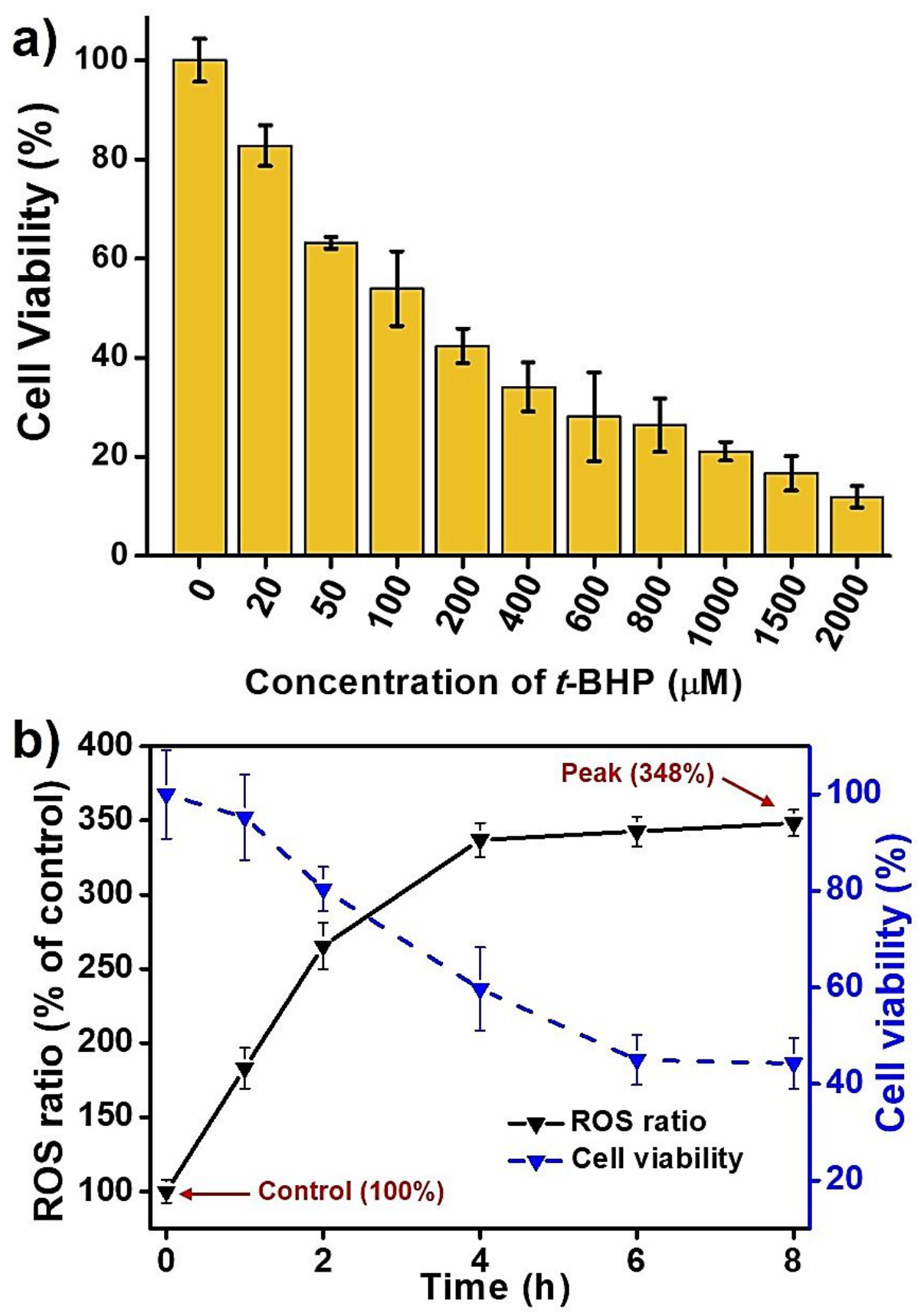

Figure S5. a) Cell viability of L929 cells treated with $t$-BHP $(0-2000 \mu \mathrm{M})$ after $24 \mathrm{~h}$.

A CCK-8 assay was used to measure cell viability. Cell viability in the culture medium was defined as $100 \%$ viability. Data are presented as mean $\pm \mathrm{SD}, \mathrm{n}=5$. b) Cell viability (CCK-8 assay) and ROS levels (DCFH-DA as a probe) in L929 cells in the presence of $t$-BHP $(200 \mu \mathrm{M})$ at different time points. Data are presented as mean $\pm \mathrm{SD}, \mathrm{n}=5$. 


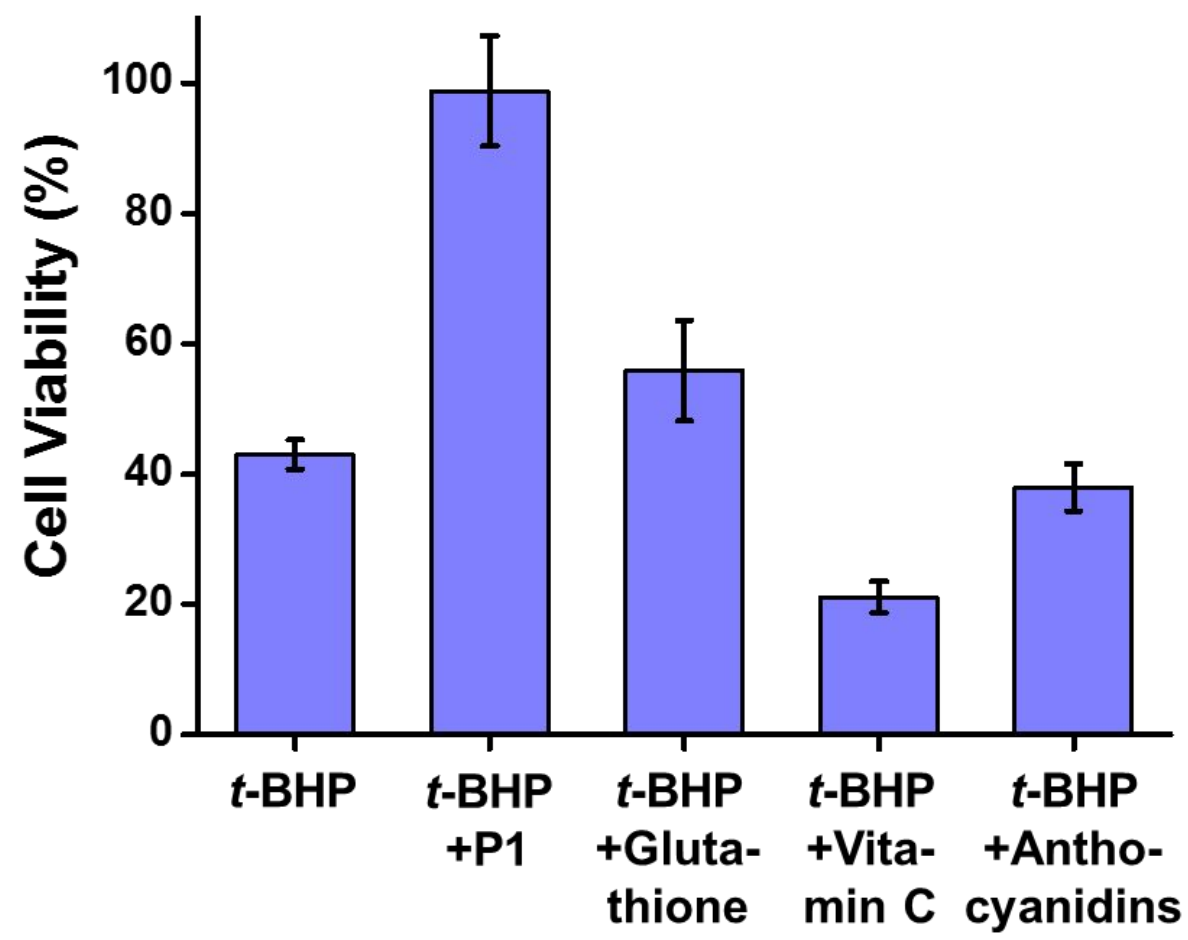

Figure S6. Cell viability of L929 cells treated with $t$-BHP $(200 \mu \mathrm{M})$ and different antioxidants after $24 \mathrm{~h}$. A CCK-8 assay was used to measure cell viability. Cell viability in the culture medium was defined as $100 \%$ viability. Data are presented as mean $\pm \mathrm{SD}$, $\mathrm{n}=5$. 


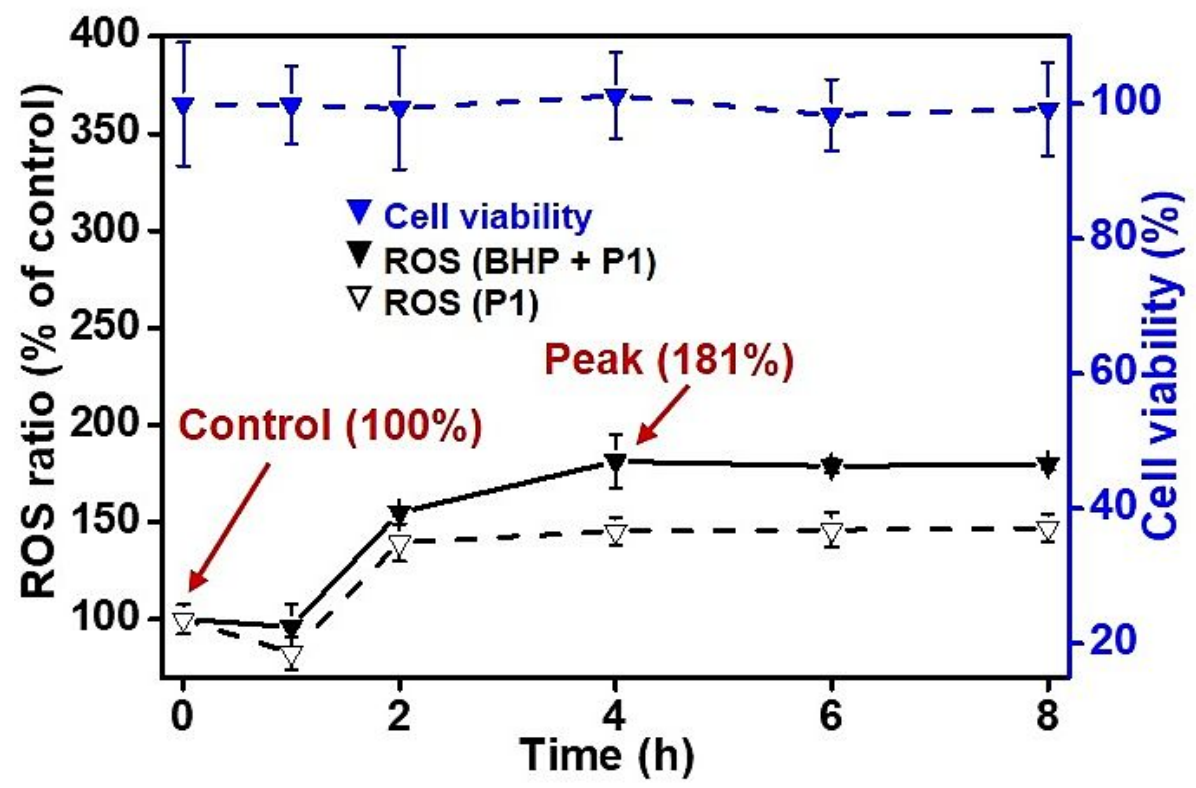

Figure S7. Cell viability and ROS levels in L929 cells in the presence of P1 $(20 \mathrm{mg} / \mathrm{mL})$ with or without $t$-BHP $(200 \mu \mathrm{M})$ at different time points. A CCK-8 assay was used to measure cell viability. Cell viability in the culture medium was defined as $100 \%$ viability. DCFH-DA was used as the probe for ROS. Data are presented as mean $\pm \mathrm{SD}$, $\mathrm{n}=5$. 


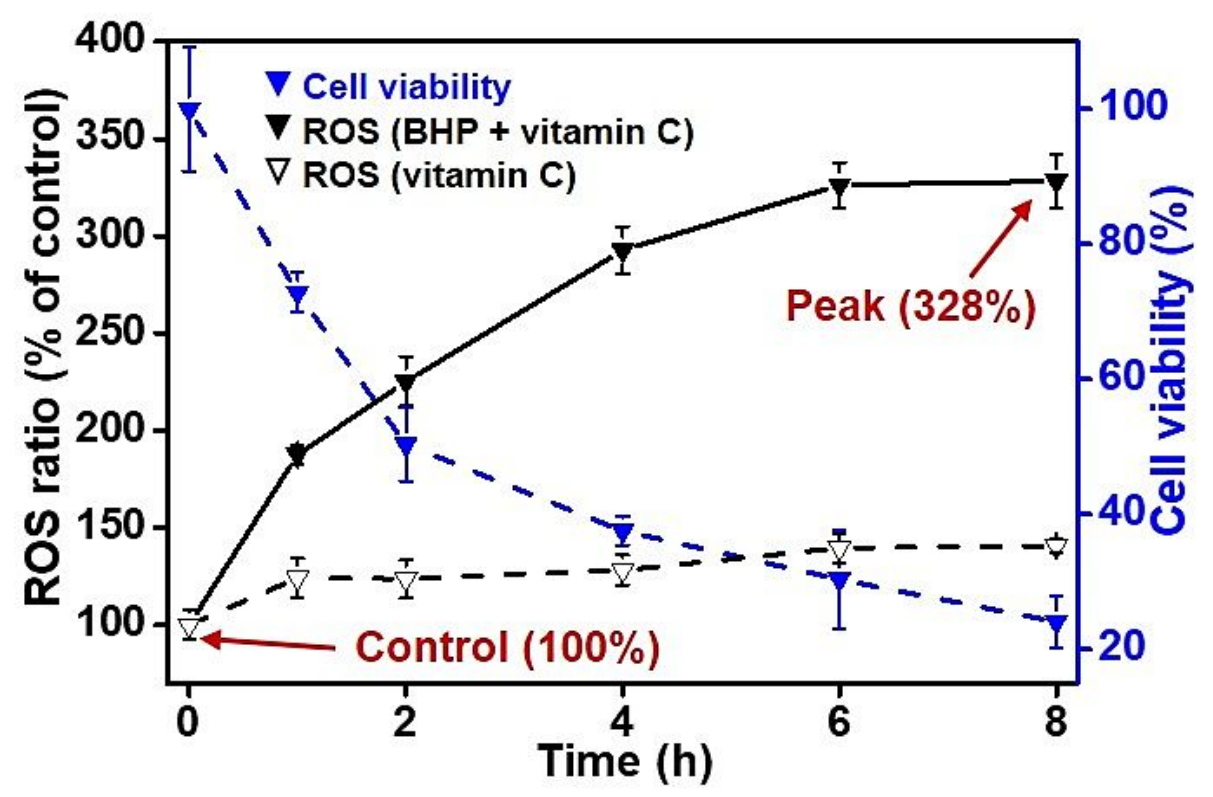

Figure S8. Cell viability and ROS levels in L929 cells in the presence of vitamin C ( 0.5 $\mathrm{mg} / \mathrm{mL})$ with or without $t$-BHP $(200 \mu \mathrm{M})$ at different time points. A CCK-8 assay was used to measure cell viability. Cell viability in the culture medium was defined as $100 \%$ viability. DCFH-DA was used as the probe for ROS. Data are presented as mean $\pm \mathrm{SD}$, $\mathrm{n}=5$. 


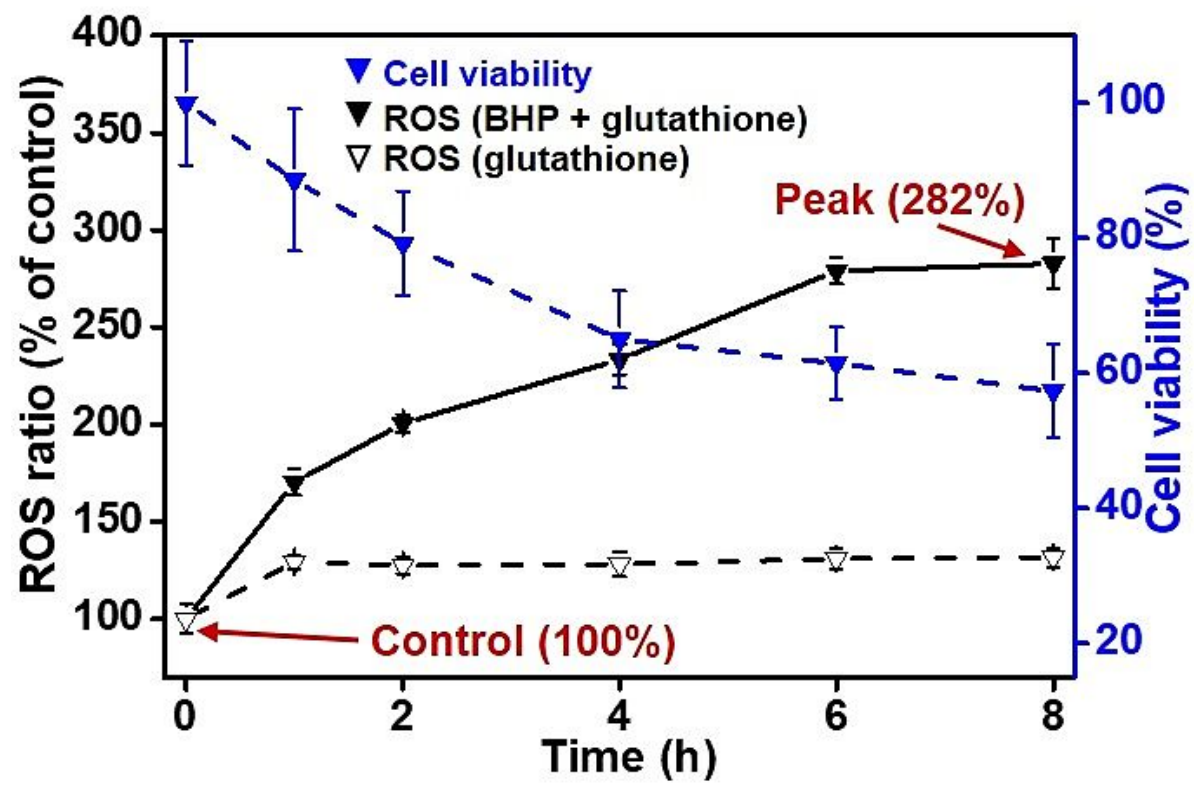

Figure S9. Cell viability and ROS levels in L929 cells in the presence of glutathione $(2 \mathrm{mg} / \mathrm{mL})$ with or without $t$-BHP $(200 \mu \mathrm{M})$ at different time points. A CCK-8 assay was used to measure cell viability. Cell viability in the culture medium was defined as $100 \%$ viability. DCFH-DA was used as the probe for ROS. Data are presented as mean $\pm \mathrm{SD}, \mathrm{n}=5$. 


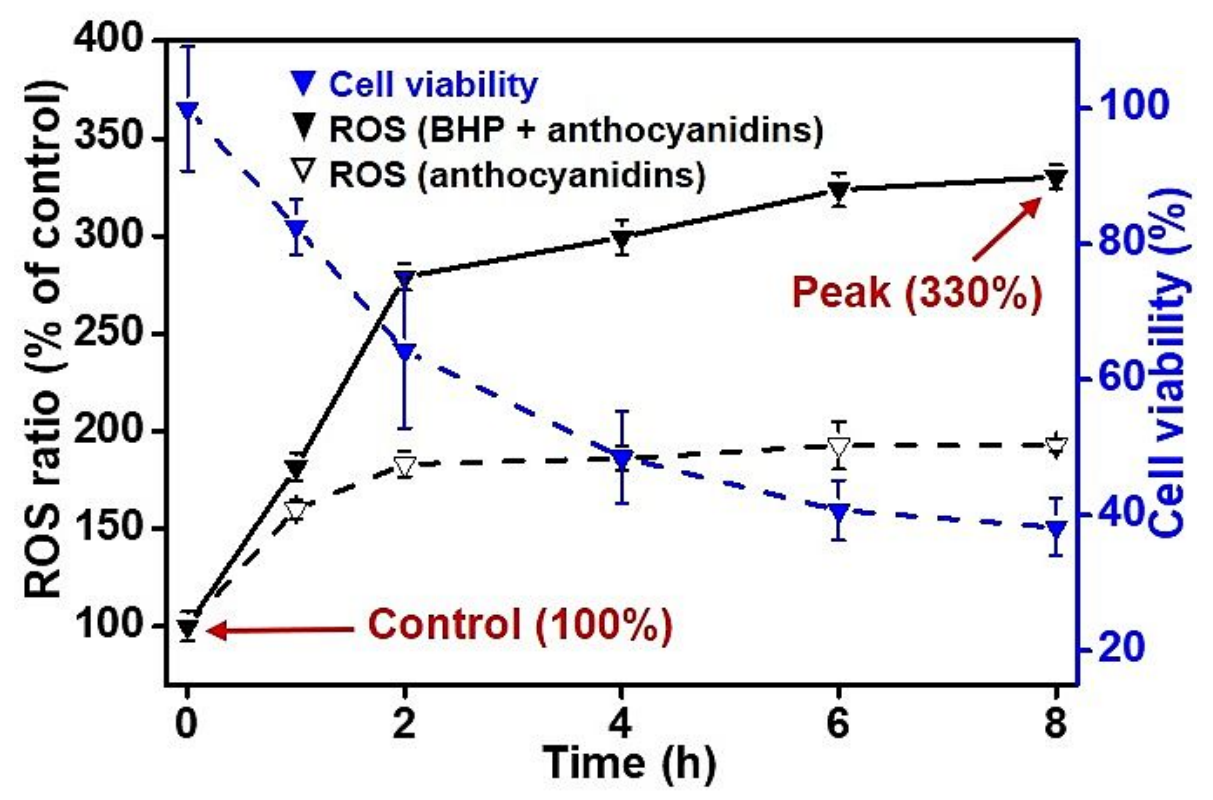

Figure S10. Cell viability and ROS levels in L929 cells in the presence of anthocyanidins $(0.13 \mathrm{mg} / \mathrm{mL})$ with or without $t$-BHP $(200 \mu \mathrm{M})$ at different time points. A CCK-8 assay was used to measure cell viability. Cell viability in the culture medium was defined as $100 \%$ viability. DCFH-DA was used as the probe for ROS. Data are presented as mean $\pm \mathrm{SD}, \mathrm{n}=5$. 

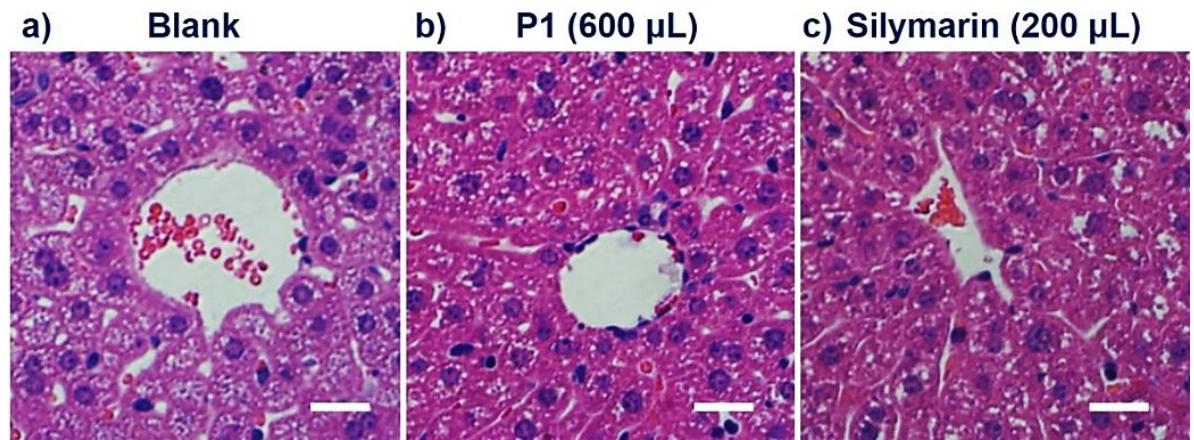

Figure S11. Histological images of liver sections in sacrificed healthy mice $24 \mathrm{~h}$ after

P1 or silymarin administration. (H\&E stained, magnification $\times 600$ ): a) Healthy mice;

b) healthy mice after intravenous tail injection of $\mathrm{P} 1(600 \mu \mathrm{L}, 20 \mathrm{mg} / \mathrm{mL})$; and c) healthy mice after intraperitoneal injection of silymarin $(200 \mu \mathrm{L}, 20 \mathrm{mg} / \mathrm{mL})$. Scale bar $=20 \mu \mathrm{m}$. 
Table S1. Properties of the synthetic copolymers

\begin{tabular}{ccccc}
\hline Copolymer & $\begin{array}{c}\text { Conversion of } \\
\text { monomers (\%) }\end{array}$ & $\begin{array}{c}\text { Ratio of } \\
\text { new group:PEG }\end{array}$ & M $_{\mathbf{n}}(\mathbf{G P C})^{\mathbf{c}}$ & PDI $^{\mathbf{c}}$ \\
\hline P1 & 95.0 & $0.93: 1$ & \\
P2 & 92.5 & $0.90: 1$ & 51900 & 1.42 \\
P3 & 95.0 & $0.91: 1$ & 91300 & 2.13 \\
\hline
\end{tabular}

a. Calculated by ${ }^{1} \mathrm{H}-\mathrm{NMR}$ (DMSO- $\left.d_{6}, 400 \mathrm{MHz}\right)$.

b. Calculated by ${ }^{1} \mathrm{H}-\mathrm{NMR}$ (DMSO- $d_{6}, 400 \mathrm{MHz}$ ).

c. Measured by GPC using DMF as the eluent ( $1 \mathrm{~mL} / \mathrm{min})$.

Table S2. ALT and AST levels in mice after different treatments

\begin{tabular}{ccc}
\hline Group & ALT (U/L) & AST (U/L) \\
\hline Blank $^{\mathrm{a}}$ & $30 \pm 8$ & $72 \pm 18$ \\
$\mathrm{CCl}_{4}{ }^{\mathrm{b}}$ & $2348 \pm 198$ & $1415 \pm 258$ \\
$\mathrm{CCl}_{4}+$ Silymarin $^{\mathrm{c}}$ & $1940 \pm 97 * *$ & $1078 \pm 26^{*}$ \\
$\mathrm{CCl}_{4}+\mathrm{P} 1(200 \mu \mathrm{L})^{\mathrm{c}}$ & $1958 \pm 198$ & $1217 \pm 77$ \\
$\mathrm{CCl}_{4}+\mathrm{P} 1(600 \mu \mathrm{L})^{\mathrm{d}}$ & $1218 \pm 168^{* *}$ & $738 \pm 114^{* *}$ \\
$\mathrm{CCl}_{4}+$ Saline $^{\mathrm{d}}$ & $2225 \pm 118$ & $1330 \pm 169$ \\
\hline
\end{tabular}

a. Healthy mice.

b. Intraperitoneal injection of $\mathrm{CCl}_{4}(0.5 \% \mathrm{v} / \mathrm{v}$ in corn oil, $50 \mu \mathrm{L})$.

c. Intraperitoneal injection, $200 \mu \mathrm{L}$.

d. Intravenous tail injection, $600 \mu \mathrm{L}$.

${ }^{*} p<0.05,{ }^{* *} p<0.01$, compared with $\mathrm{CCl}_{4}$ group. 
Table S3. Levels of ALT, AST, MDA, and SOD in healthy mice after the various treatments

\begin{tabular}{ccccc}
\hline Group & ALT(U/L) & AST(U/L) & $\begin{array}{c}\text { MDA } \\
\text { (nmol/mg protein) }\end{array}$ & $\begin{array}{c}\text { SOD } \\
\text { (U/mg protein) }\end{array}$ \\
\hline Blank $^{\mathrm{a}}$ & $30 \pm 8$ & $72 \pm 18$ & $3.76 \pm 0.54$ & $175.47 \pm 6.13$ \\
Silymarin $^{\mathrm{b}}$ & $55 \pm 7^{* *}$ & $133 \pm 15^{* *}$ & $4.21 \pm 0.55$ & $163.01 \pm 7.44^{*}$ \\
$\mathrm{P} 1^{\mathrm{c}}$ & $22 \pm 8$ & $92 \pm 15$ & $4.66 \pm 0.48^{*}$ & $164.97 \pm 9.52^{*}$ \\
\hline
\end{tabular}

a. Healthy mice.

b. Intraperitoneal injection of silymarin $(20 \mathrm{mg} / \mathrm{mL}, 200 \mu \mathrm{L})$.

c. Intravenous tail injection of P1 $(20 \mathrm{mg} / \mathrm{mL}, 600 \mu \mathrm{L})$.

${ }^{*} p<0.05,{ }^{*} p<0.01$, compared with the blank.

\section{References}

1. Mao, T. F.; Liu, G. Q.; Wu, H. B.; Wei, Y.; Gou, Y. Z.; Wang, J.; Tao, L., High Throughput Preparation of UV-Protective Polymers from Essential Oil Extracts via the Biginelli Reaction. J. Am. Chem. Soc. 2018, 140 (22), 6865-6872.

2. Xu, F.; Li, H.; Luo, Y. L.; Tang, W., Redox-Responsive Self-Assembly Micelles from Poly(N-acryloylmorpholine-block-2-acryloyloxyethyl ferrocenecarboxylate) Amphiphilic Block Copolymers as Drug Release Carriers. ACS Appl. Mater. Inter. 2017, 9 (6), 5181-5192.

3. Scott, S. L.; Chen, W. J.; Bakac, A.; Espenson, J. H., Spectroscopic Parameters, Electrode-Potentials, Acid Ionization-Constants, and Electron-Exchange Rates of the 2,2'-Azinobis(3-Ethylbenzothiazoline-6-Sulfonate) Radicals and Ions. J. Phys. Chem. 1993, 97 (25), 6710-6714.

4. Wang, R.; Liu, Z. Q., Ugi Multicomponent Reaction Product: The Inhibitive Effect on DNA Oxidation Depends upon the Isocyanide Moiety. J. Org. Chem. 2013, 78 (17), 8696-8704.

5. Wang, H.; Joseph, J. A., Quantifying cellular oxidative stress by dichlorofluorescein assay using microplate reader. Free Radical Bio. Med. 1999, 27 (5-6), 612-616.

6. Jones, K. H. S., J. A., An Improved Method to Determine Cell Viability by Simultaneous Staining with Fluorescein Diacetate Propidium Iodide. J. Histochem. Cytochem. 1985, 33 (1), 77-79.

7. Parveen, R.; Baboota, S.; Ali, J.; Ahuja, A.; Vasudev, S. S.; Ahmad, S., Oil based nanocarrier for improved oral delivery of silymarin: In vitro and in vivo studies. Int. J. Pharmaceut. 2011, 413 (1-2), 245-253. 